\title{
Cluster analysis and geochemical processes for the characterization of the aquifer system in Maracanã/São Luis/MA
}

\author{
Análise de agrupamentos e processos geoquímicos para caracterização do \\ sistema aqüífero no Maracanã/São Luís/MA
}

\author{
João Batista Almeida ${ }^{1}$, João Filomeno Barros ${ }^{1}$, Bruno Alves de Mesquita ${ }^{2}$, Carla Maria Salgado Vidal Silva ${ }^{2}$, \\ Josué Mendes Filho ${ }^{2}$, Horst Frischkorn ${ }^{2}$ and Maria Marlúcia Freitas Santiago ${ }^{2}$ \\ ${ }^{1}$ Instituto Federal do Maranhão, São Luís, MA, Brazil \\ ${ }^{2}$ Universidade Federal do Ceará, Fortaleza, CE, Brazil \\ E-mails: bvapalmeida@yahoo.com.br (JBA), rennan.barros@hotmail.com (JFB), bruno.mesquita@fisica.ufc.br (BAM), \\ carla@fisica.ufc.br(CMSVS),josue@fisica.ufc.br(JMF), cariri@ufc.br(HF), marlucia@fisica.ufc.br (MMFS)
}

\begin{abstract}
To better know the aquifer system in the Maracanã Environmental Protection Area were collected samples in four campaigns; the first during the drought season and the others in the following rainy one. The water samples were analised for eleven hydrochemical parameters, $\mathrm{CE}, \mathrm{Ca}^{2+}, \mathrm{Mg}^{2+}, \mathrm{Na}^{+}, \mathrm{K}^{+}, \mathrm{Cl}^{-}, \mathrm{SO}_{4}^{2-}, \mathrm{HCO}_{3}^{-}, \mathrm{NO}_{3}^{-}, \mathrm{Fe}$ and P. Cluster analysis separated the wells in the area, identifing three different groups that exploit water with electrical conductivity in the ranges of 230 to $400 \mu \mathrm{S} / \mathrm{cm}, 87$ to $210 \mu \mathrm{S} / \mathrm{cm}$, and 22 to $64 \mu \mathrm{S} / \mathrm{cm}$, respectively. Data show a predominance of sodium chlorinated water. With these results and identification of geochemical processes determined by changes in concentrations of $\mathrm{Fe}$ and $\mathrm{P}$ it was possible to develop a model that identifies the aquifer of the aquifer system exploited by each well.
\end{abstract}

Keywords: Groundwater; Iron; Phosphorous; Maracanã APA; Aquifer system model.

\section{RESUMO}

Para conhecer o sistema aquífero na área de Proteção Ambiental do Maracanã foram coletadas amostras de água em quatro campanhas; a primeira no período seco e as outras no período chuvoso seguinte. Foram analisados nas águas amostradas onze parâmetros hidroquímicos $\mathrm{CE}, \mathrm{Ca}^{2+}, \mathrm{Mg}^{2+}, \mathrm{Na}^{+}, \mathrm{K}^{+}, \mathrm{Cl}^{-}, \mathrm{SO}_{4}^{2-}, \mathrm{HCO}_{3}^{-}, \mathrm{NO}_{3}$, Fe e P. A análise de agrupamentos separou os poços na área, identificando três grupos distintos que explotam águas com condutividade elétrica nas faixas de 230 a $400 \mu \mathrm{S} / \mathrm{cm}, 87$ a $210 \mu \mathrm{S} / \mathrm{cm}$ e 22 a $64 \mu \mathrm{S} / \mathrm{cm}$; os dados mostraram predominância de águas cloretadas sódicas e recarga rápida. Com estes resultados e identificação de processos geoquímicos determinados pelas mudanças nas concentrações de Fe e P foi possível desenvolver um modelo que identificou os aquíferos do sistema de aquíferos explotado por cada poço.

Palavras-chave: Água subterrânea; Ferro; Fosforo; APA do Maracanã; Modelo de sistema aquífero. 


\section{INTRODUCTION}

Population growth is accompanied by the expansion of the occupied land area and water demand for human consumption and agriculture, among other needs. Thus, surface water reserves are no longer sufficient to meet the new needs, either by insufficient volume, either by the quality of waters which is vulnerable to anthropic action.

Groundwater became an important water reserve that can help to contribute the demands of water. However, the exploitation of these waters requires knowledge of the reserve so its consumption occurs for sustainability; the recharge areas should be protected to maintain adequate quality consume and exploited volume should be subject to natural recharge conditions not to exhaust the reserve.

In the Maracanã Environmental Protection Area, anthropic actions are easily identified; deforestation of the area that allows the soil entrainment to the streams already cause siltation of watersheds. Also, the lack of sanitation led to the construction of septic tanks or black, used to meet the shortage of sewage, which are installed in inappropriate places, often near surface reserves and wells. In this context, groundwater is already an important source of water supply for human consumption threatened by man.

The knowledge of the reserve will allow doing extraction without compromising quality and quantity. The cluster analysis, multivariate statistical technique is a useful tool when it aims to identify groups with similar hydrochemical characteristics. This technique has been used to study water quality (GASTMANS; MENEGÁRIO; MOURA, 2013; LIMA et al., 2011; SALGADO et al., 2011; MONTEIRO et al., 2010; SILVA et al., 2013), and assists in the interpretation processes that affects the chemical composition of groundwater.

This technique was applied by Meng and Maynard (2001) in the development of conceptual models of geochemical behavior for aquifer Botucatu/SP, which identified three distinct geochemically regions. Moreover, Oyebog et al. (2012) used cluster analysis to correlate eight different brands of bottled water sold in Cameroon - Africa.

Güler et al. (2002) reported the technical efficiency, cluster analysis, in the formation of groups regarding similarity parameters when working with a large number of data. However, it points out that this statistical technique does not provide information of the chemistry of the groups formed, with the need to combine it with specific graphic techniques such as Piper diagram, for consistent media in the chemical classification of water to a large number of data.

This work deals with the characterization of groundwater in the area and the conditions of storage in the aquifer system through statistical analysis of major ions concentrations data and geochemical processes involving $\mathrm{Fe}$ and $\mathrm{PO}_{4}{ }^{3-}$.

\section{AREA}

The Maracanã neighborhood, located in the countryside of São Luis, was installed in 1991 of the Maracanã Environmental Protection Area, where is the IFMA (Federal Institute of Maranhão) Campus São Luís Maracanã. Environmental management of area, to minimize the existing degradation process, it was discussed by
Ribeiro dos Santos and Cézar dos Santos (SANTOS; SANTOS, 2009).

The annual precipitation amount in region normally exceeds $2000 \mathrm{~mm}$, contributing to the rains causing erosion and strong leaching, which weakens the soil (IFMA, 2009); rainfall is distributed between the months of January and July, with the most intense in March and April. The River Plate is located in the area and its waters are dammed forming a lake. The altitude difference of $20 \mathrm{~m}$ between the watershed and the surrounding region directs the runoff and the variation of conditions stratigraphy infiltration recharging aquifers.

The groundwater represent the main water reserve for public consumption in the study area; they are stored in geological structures, from bottom to top following: i) Itapecuru Formation, Cretaceous period, contains limestone, clay and groundwater as mineral potential; ii) Formation Paleogene, Paleogene period, it has clay, laterite and groundwater as mineral potential; iii) Barreiras, Meso-Miocene period, separated into two facies, sandy-loam and sandy, with mineral potential, clay, laterite and groundwater (PEREIRA; ZAINE, 2007).

\section{MATERIALS AND METHODS}

Samples of 14 wells were collected in four campaigns in the locations indicated in Figure 1; the first, in the dry season (December/2011) and the other three in the rainy season, one at the beginning (February/2012), one in the middle (April/2012) and another at the end (July/2012) of the period. Electrical conductivity measurements were carried out in the field with multiparameter equipment - Instruterm.

In the Laboratory of FUNASA/Maranhão, were analysed $\mathrm{Ca}^{2+}, \mathrm{Mg}^{2+}, \mathrm{Cl}^{-}$and $\mathrm{HCO}_{3}$, using titration method; $\mathrm{Na}^{+}$e $\mathrm{K}^{+}$were measured in Hydrochemistry Laboratory of Physics Department of the UFC, by flame photometry; and SO42-, NO3-, Fe and P, analyzed in FUNASA using spectrophotometer Huch, model 2800. Ionic balance, designed to assess the quality of analytical results using the method of Custodio and Llamas (1983) showed that all results are in agreement with the allowable errors.

Rock analyzes were carried out by X-ray diffractometer powder, Bruker, UFC Department of Physics and the identification of components by JCPDS library.

In order to classify the water as the predominant cations and anions were used Piper diagrams created with software OriginPro 9.1.

To identify the groups was used the cluster analysis, a multivariate statistical technique. In this type of analysis, hierarchical cluster or dendrograms were constructed using OriginPro 9.1 software. The linkage type used was the method of Ward Junior (1963), which was selected for its efficiency in combining groups of approximately equal size, due to its minimization of internal variation (HAIR et al., 2005). In this method, the cluster is made from the analysis of variance to determine the degree of similarity between the groups consisting in each stage resulting solution group with the smallest sum of squares, made on all variables (SHARMA, 1996). In order to calculate the similarity between the wells was used the Euclidean distance, measured distance most frequently used when all variables are quantitative (SEIDEL et al., 

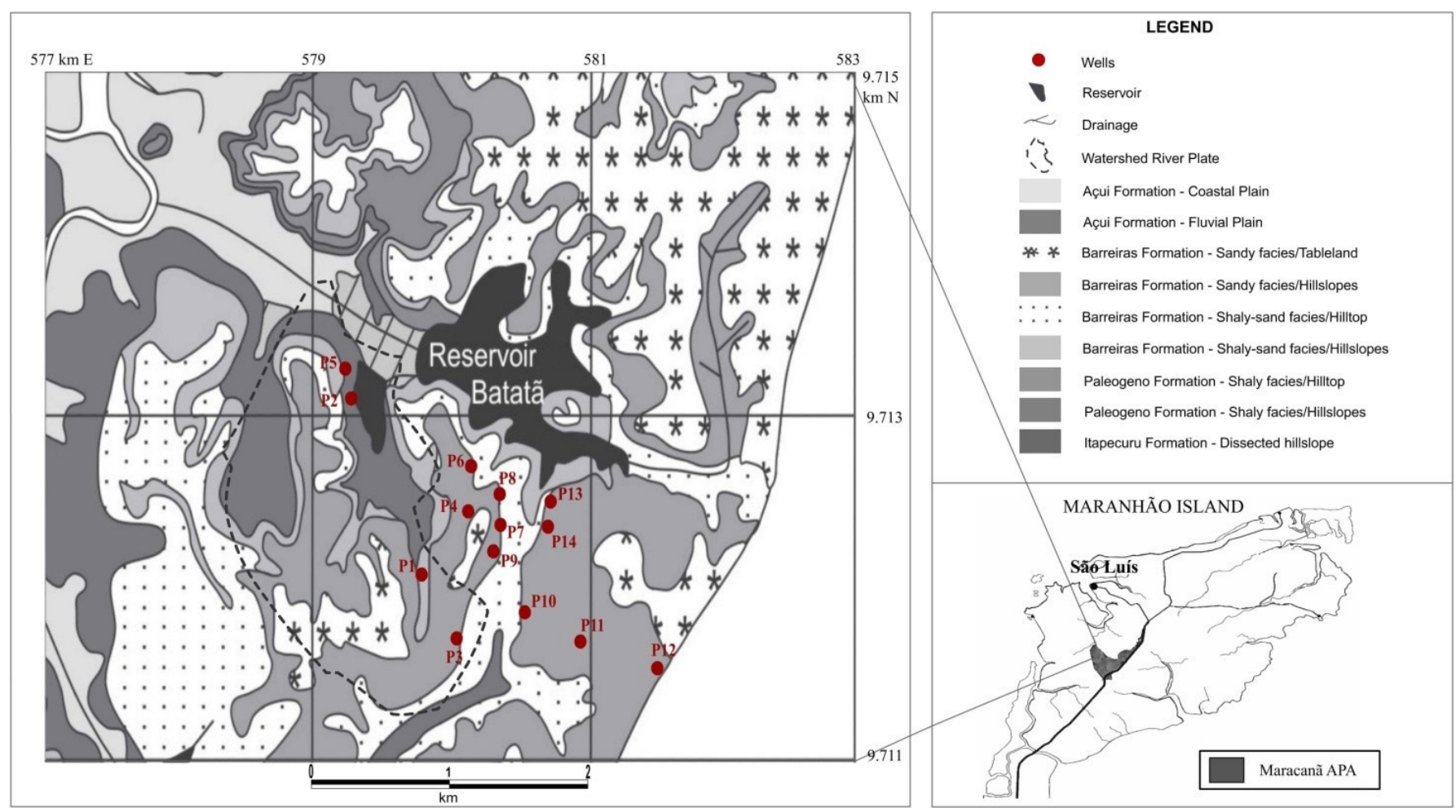

Figure 1. Location of sampling sites (modified PEREIRA; ZAINE, 2007) and APA of Maranhão (modified REIS, 2012).

2008). The Euclidean distance is the geometric distance in a space of $\mathrm{p}$ dimensions, being set to two individuals $\mathrm{i}$ and $\mathrm{j}$, by:

$d_{i j}=\sqrt{\sum_{k=1}^{p}\left(z_{i k}+z_{j k}\right)}$

Where, $Z_{\mathrm{ik}}$ is $\mathrm{k}$-th feature for the $\mathrm{i}$-th individual $\mathrm{e} \mathrm{Z}_{\mathrm{j} \mathrm{k}}$ is $\mathrm{k}$-th feature for the $j$-th individual. As smaller the Euclidean distance is, more similar are the objects compared.

\section{RESULTS AND DISCUSSION}

In Cluster Analysis, we evaluated the concentrations of calcium, magnesium, sodium, potassium, chloride, bicarbonate, sulphate and nitrate (Table 1). The iron and phosphorus concentrations, also presented in this table, were not included in this analysis due to their relatively lower concentrations than those found in other parameters. All major ions concentrations were well below the VMP (BRASIL, 2011): $\mathrm{Na}^{+}=200 \mathrm{mg} / \mathrm{L}$, $\mathrm{Cl}^{-}=\mathrm{SO}_{4}{ }^{2-}=\mathrm{HCO}_{3}^{-}=250 \mathrm{mg} / \mathrm{L}$ ). Iron concentrations were higher than VMP $(0.3 \mathrm{mg} / \mathrm{L})$ in five samples collected in December $/ 2011$. The nitrate concentration only exceeded the VMP $(10 \mathrm{mg} / \mathrm{L}$, BRASIL, 2008) in the well P10 in December/2010.

Cluster Analysis results of samples in the two periods (dry and rainy) are shown by the dendrogram in Figure 2. They show that the wells are combined into three clusters: Cluster 1, the most saline water (230 to $400 \mu \mathrm{S} / \mathrm{cm}$ ); Cluster $2 \mathrm{~A}$, with intermediate water salinity ( 87 to $210 \mu \mathrm{S} / \mathrm{cm}$ ); and Cluster $2 \mathrm{~B}$ of water with lower salinity (22 to $64 \mu \mathrm{S} / \mathrm{cm}$ ).
Figure 2 shows that the recharge in the rainy season saved three clusters, but changed the dissimilarity between them. In this period, in April, recharging was quick in P11 and P12 wells, reducing the salinity of the water, passing from Cluster 1 to Cluster 2A, but showing different dissimilarity in relation to other wells in this cluster. The P3 dried at the end of the rainy season, after the third collection. P2 while remaining in Cluster $2 \mathrm{~B}$, at the beginning of the rainy season the dissimilarity increased compared to the others of their cluster, while in the middle and at the end of this period was associated with the P14. It is important to note that the 2011 rainy season had annual rainfall of $2487.7 \mathrm{~mm}$, above average and in 2012, was only $1056.7 \mathrm{~mm}$ (measured at the Meteorological Station of the State University of Maranhão). The influence of recharge is only effective in the third collection - April/2012 (Figure 3), for the following months the monthly precipitation was relatively small.

Figure 4 shows the conductivity values of samples collected in the four campaigns, associated with the formed clusters. The third collection, saved three wells (P3, P5 and P13), the values are lower than the first, indicating rapid recharge in the rainy season.

Piper diagrams of the water samples collected in the dry period (December/2011) and rainy period, (February/2012, April/2012, July/2012), respectively, are shown in Figure 5. Note that the four water campaigns they are sodium chloride types; exceptions are samples of P3 (mixed bicarbonate) in December/2011 and P10 (sodium bicarbonate) and P14 (sodium mixed) in April/2012.

The $\mathrm{x}$-ray analysis of samples taken from various points in the sub-surface area shows that the soil is rich in iron minerals such as bixbyta $\left(\mathrm{FeMnO}_{3}\right)$ and hematite $\left(\mathrm{Fe}_{2} \mathrm{O}_{3}\right)$ and with silica 
Table 1. Hydrochemical samples from two collections.

\begin{tabular}{|c|c|c|c|c|c|c|c|c|c|c|c|}
\hline \multirow{2}{*}{ Well } & $\mathrm{Ca}^{2+}$ & $\mathrm{Mg}^{2+}$ & $\mathrm{Na}^{+}$ & $\mathbf{K}^{+}$ & $\mathrm{Cl}^{-}$ & $\mathrm{HCO}_{3}^{-}$ & $\mathrm{SO}_{4}^{2-}$ & $\mathrm{NO}_{3}^{-}$ & $\mathrm{Fe}$ & $\mathbf{P}$ & \multirow{2}{*}{$\begin{array}{c}\mathrm{EC} \\
(\mu \mathrm{S} / \mathrm{cm})\end{array}$} \\
\hline & \multicolumn{10}{|c|}{$(\mathrm{mg} / \mathrm{L})$} & \\
\hline \multicolumn{12}{|c|}{ Dec/2011 } \\
\hline P1 & 1.44 & 0.87 & 8.37 & 2.41 & 18.2 & 7.24 & 0.09 & 2.20 & 0.09 & 0.02 & 64 \\
\hline P2 & 0.84 & 0.51 & 3.18 & 1.20 & 5.6 & 8.56 & 0.17 & 0.30 & 0.07 & 0.01 & 30 \\
\hline P3 & 28.0 & 17.00 & 20.20 & 3.61 & 28.6 & 82.80 & 4.52 & 0.80 & $<\mathrm{LQ}$ & 0.12 & 310 \\
\hline P4 & 3.80 & 2.31 & 15.90 & 2.41 & 30.4 & 9.99 & 0.09 & 2.70 & $<\mathrm{LQ}$ & 0.06 & 101 \\
\hline P5 & 1.96 & 1.19 & 5.39 & 1.20 & 9.95 & 8.05 & 0.01 & 1.90 & 0.09 & 0.04 & 46 \\
\hline P6 & 1.40 & 0.85 & 6.39 & 2.41 & 11.4 & 9.07 & 0.09 & 1.90 & 0.05 & 0.02 & 50 \\
\hline P7 & 3.40 & 2.06 & 11.8 & 3.61 & 29.2 & 7.03 & 0.09 & 1.20 & 0.72 & 0.09 & 101 \\
\hline P8 & 1.56 & 0.95 & 6.08 & 2.41 & 14.0 & 7.54 & 0.09 & 2.20 & 0.77 & 0.04 & 52 \\
\hline P9 & 2.08 & 1.26 & 11.80 & 3.61 & 27.0 & 6.52 & 0.09 & 4.30 & 0.52 & 0.06 & 100 \\
\hline P10 & 27.20 & 16.5 & 59.20 & 7.21 & 138 & 10.30 & 0.09 & 18.40 & 0.22 & 0.09 & 400 \\
\hline P11 & 9.96 & 6.04 & 32.30 & 2.41 & 70.3 & 10.90 & 0.01 & 5.00 & 0.07 & 0.38 & 230 \\
\hline $\mathrm{P} 12$ & 8.10 & 0.97 & 48.40 & 2.41 & 70.9 & 35.30 & 0.17 & 7.70 & 0.32 & 0.75 & 297 \\
\hline P13 & 4.72 & 2.86 & 11.80 & 3.61 & 33.3 & 7.65 & 0.09 & 0.70 & 0.30 & 0.02 & 117 \\
\hline P14 & 1.36 & 0.83 & 5.08 & 2.41 & 11.4 & 10.40 & 0.17 & 0.40 & 0.54 & 0.00 & 50 \\
\hline \multicolumn{12}{|c|}{ Feb/2012 } \\
\hline P1 & 3.48 & 0.45 & 8.37 & 2.41 & 18.65 & 8.5 & 0.09 & 3.2 & 0.07 & 0.11 & 67 \\
\hline P2 & 1.32 & 0.17 & 33.16 & 0.1 & 5.1 & 7.2 & 0.09 & 0.5 & 0.04 & 0.03 & 26 \\
\hline P3 & 20.04 & 1.91 & 53.16 & 4.81 & 42.3 & 99.9 & 3.86 & 0.7 & 0.03 & 0.1 & 377 \\
\hline P4 & 3.96 & 0.26 & 15.92 & 2.41 & 32.05 & 8.6 & 0.09 & 3.6 & 0.05 & 0.06 & 105 \\
\hline P5 & 2.24 & 0.26 & 8.08 & 1.2 & 10.65 & 9.0 & 0.09 & 0.6 & 0.04 & 0.04 & 52 \\
\hline P6 & 2.24 & 0.27 & 6.39 & 2.41 & 14.15 & 10 & 0.01 & $<\mathrm{LQ}$ & 0.05 & 0.03 & 56 \\
\hline P7 & 3.1 & 0.42 & 18.22 & 3.61 & 36.55 & 17.8 & 0.09 & 3.9 & 0.35 & 0.08 & 107 \\
\hline P8 & 1.43 & 0.18 & 6.73 & 2.41 & 14.9 & 7.5 & 0.52 & 2.0 & 0.48 & 0.04 & 55 \\
\hline P9 & 3.12 & 0.39 & 14.07 & 3.61 & 31.3 & 7.9 & 0.09 & 3.2 & 0.28 & 0.04 & 96 \\
\hline P10 & 24.28 & 0.96 & 33.16 & 3.62 & 92.15 & 12.3 & 0.09 & 9.9 & 0.1 & 0.04 & 278 \\
\hline P11 & 5.2 & 0.8 & 35.5 & 3.2 & 71.2 & 7.5 & 0.01 & 8.5 & 0.06 & 0.18 & 210 \\
\hline P12 & 15.3 & 0.06 & 45.66 & 2.41 & 89.25 & 10.8 & 0.17 & 7.7 & 0.27 & 0.24 & 282 \\
\hline $\mathrm{P} 13$ & 4.0 & 1.26 & 10.75 & 3.61 & 28.3 & 7.7 & 0.17 & 2.8 & 0.2 & 0.03 & 126 \\
\hline P14 & 1.68 & 0.24 & 5.04 & 3.61 & 8.75 & 7.1 & 5.19 & 0.5 & 0.18 & 0.01 & 39 \\
\hline \multicolumn{12}{|c|}{ Apr/2012 } \\
\hline P1 & 1.20 & 1.01 & 7.23 & 2.41 & 14.1 & 9.42 & 0.78 & 0.5 & 0.10 & 0.01 & 59 \\
\hline P2 & 0.38 & 0.99 & 2.62 & 1.21 & 3.8 & 5.51 & 0.78 & 0.4 & $<\mathrm{LQ}$ & 0.01 & 22 \\
\hline P3 & 24.50 & 4.09 & 55.3 & 4.81 & 90.7 & 41.2 & 4.71 & 0.4 & $<\mathrm{LQ}$ & 0.06 & 339 \\
\hline P4 & 4.20 & 0.83 & 13.00 & 2.41 & 31.2 & 9.80 & 0.35 & 0.1 & $<\mathrm{LQ}$ & 0.01 & 102 \\
\hline P5 & 1.44 & 0.97 & 6.84 & 2.41 & 13.9 & 9.06 & 0.01 & 0.4 & $<\mathrm{LQ}$ & 0.03 & 57 \\
\hline P6 & 1.04 & 1.32 & 5.84 & 2.61 & 15.3 & 7.10 & 0.01 & 0.4 & $<\mathrm{LQ}$ & 0.01 & 52 \\
\hline P7 & 1.92 & 1.24 & 12.6 & 3.61 & 32.2 & 8.30 & 0.01 & 0.4 & 0.10 & 0.01 & 96 \\
\hline P8 & 1.64 & 0.96 & 7.01 & 2.61 & 10.8 & 10.40 & 0.01 & 0.5 & 0.10 & 0.02 & 53 \\
\hline P9 & 2.88 & 0.71 & 12.50 & 2.41 & 26.5 & 8.50 & 0.01 & 0.4 & $<\mathrm{LQ}$ & 0.01 & 87 \\
\hline P10 & 8.08 & 1.97 & 34.30 & 2.21 & 44.8 & 82.30 & 0.01 & 0.4 & 0.02 & 0.01 & 288 \\
\hline P11 & 4.00 & 1.50 & 36.20 & 3.70 & 23.0 & 8.00 & 0.09 & 0.4 & 0.05 & 0.03 & 206 \\
\hline $\mathrm{P} 12$ & 1.60 & 1.20 & 45.40 & 2.41 & 21.0 & 7.90 & 0.17 & 0.4 & 0.07 & 0.02 & 200 \\
\hline P13 & 6.00 & 0.90 & 21.30 & 3.61 & 35.1 & 10.40 & 0.01 & 0.0 & 0.05 & 0.01 & 130 \\
\hline P14 & 0.72 & 0.56 & 5.62 & 0.61 & 5.8 & 7.55 & 5.19 & 0.7 & 0.05 & 0.01 & 33 \\
\hline \multicolumn{12}{|c|}{ Jul/2012 } \\
\hline P1 & 2.84 & 0.27 & 9.36 & 2.41 & 14.5 & 5.8 & 0.09 & 3.1 & 0.06 & 0.09 & 57 \\
\hline $\mathrm{P} 2$ & 1.12 & 0.12 & 2.21 & 0.41 & 5.8 & 2.8 & 0.52 & 0.5 & 0.06 & 0.03 & 20 \\
\hline P4 & 3.12 & 0.11 & 15.97 & 2.41 & 32.35 & 10.8 & 0.17 & 3.6 & 0.03 & 0.07 & 101 \\
\hline P5 & 1.71 & 0.12 & 6.84 & 2.41 & 11.95 & 8.3 & 0.54 & 1.7 & 0.08 & 0.04 & 51 \\
\hline P6 & 1.71 & 0.16 & 7.23 & 2.41 & 12.25 & 9.2 & 0.17 & 2.0 & 0.02 & 0.01 & 55 \\
\hline P7 & 2.15 & 0.1 & 14.29 & 2.41 & 29.4 & 7.0 & 0.52 & 2.9 & 0.24 & 0.01 & 93 \\
\hline P8 & 1.53 & 0.12 & 6.61 & 2.41 & 13.3 & 7.1 & 0.07 & 1.6 & 0.05 & 0.01 & 49 \\
\hline P9 & 1.4 & 0.32 & 12.72 & 3.62 & 25.55 & 6.1 & 0.09 & 3.7 & 0.06 & 0.01 & 80 \\
\hline P10 & 7.9 & 0.99 & 47.46 & 2.41 & 86.7 & 16 & 0.09 & 6.9 & 0.11 & 0.04 & 260 \\
\hline P11 & 1.2 & 0.09 & 47.38 & 3.25 & 69.35 & 40.2 & 0.05 & 5.6 & 0.04 & 22 & 223 \\
\hline P12 & 14.6 & 2.43 & 51.91 & 3.62 & 82.1 & 54.3 & 0.15 & 4.4 & 0.28 & 0.01 & 318 \\
\hline P13 & 4.84 & 1.29 & 19.95 & 3.62 & 45.3 & 7.8 & 0.09 & 5.5 & 0.04 & 0.02 & 130 \\
\hline P14 & 1.2 & 0.5 & 6.01 & 2.41 & 8.95 & 6.2 & 4.71 & 0.8 & 0.15 & 0.01 & 41 \\
\hline
\end{tabular}

LQ: Limit of Quantification, EC: electrical conductivity. 
a)

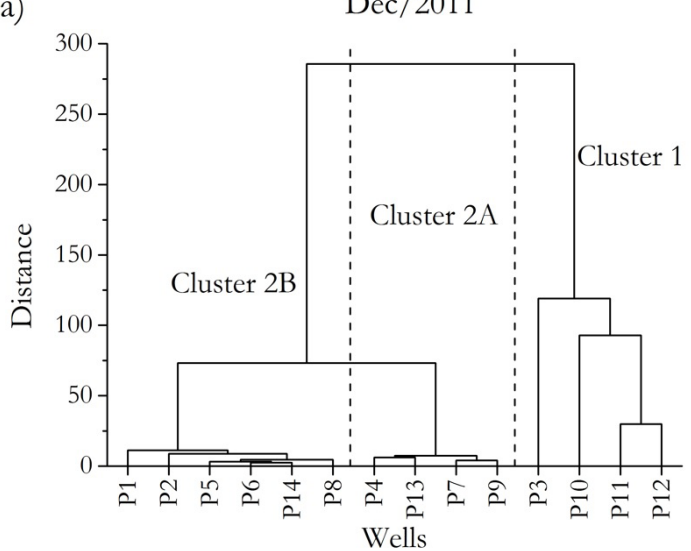

b)

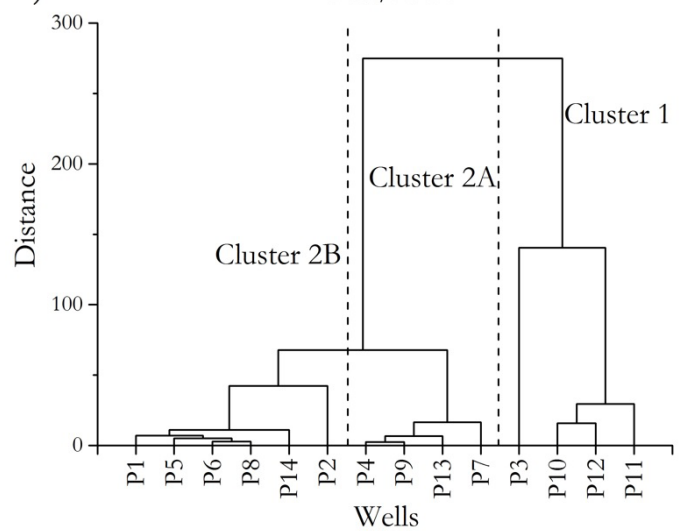

c)

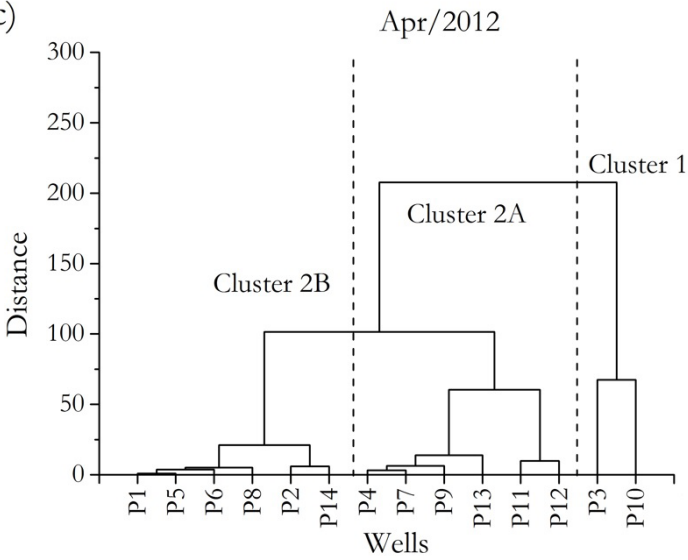

d)

Jul/2012

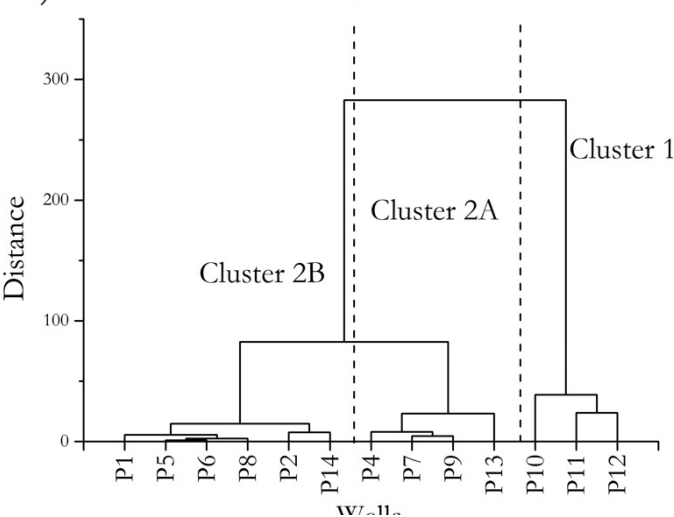

Figure 2. Hierarchical dendrogram of all samples: (a) dry period, (b) at the beginning, (c) in the middle, (d) at the end of the rainy season.

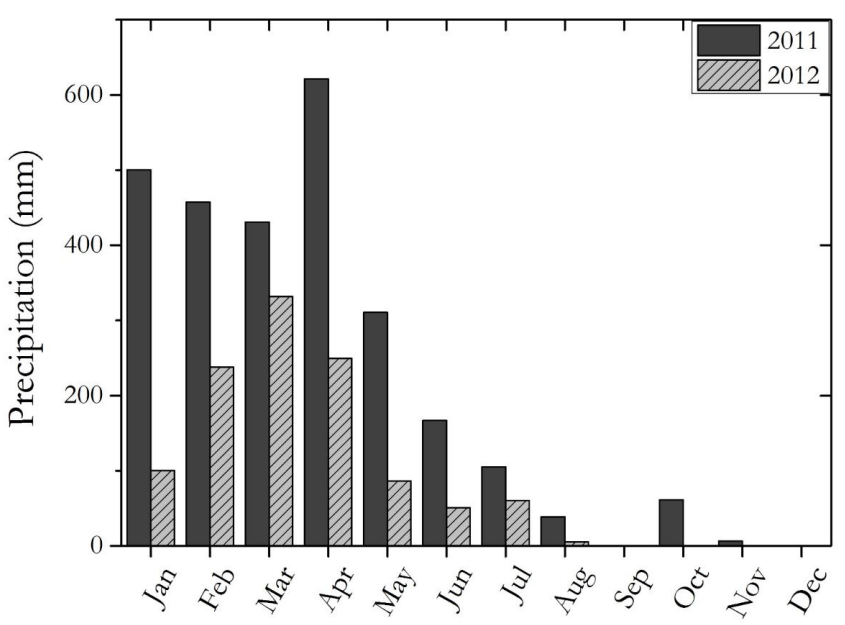

Figure 3. Precipitation histogram from January 2011 to December 2012.

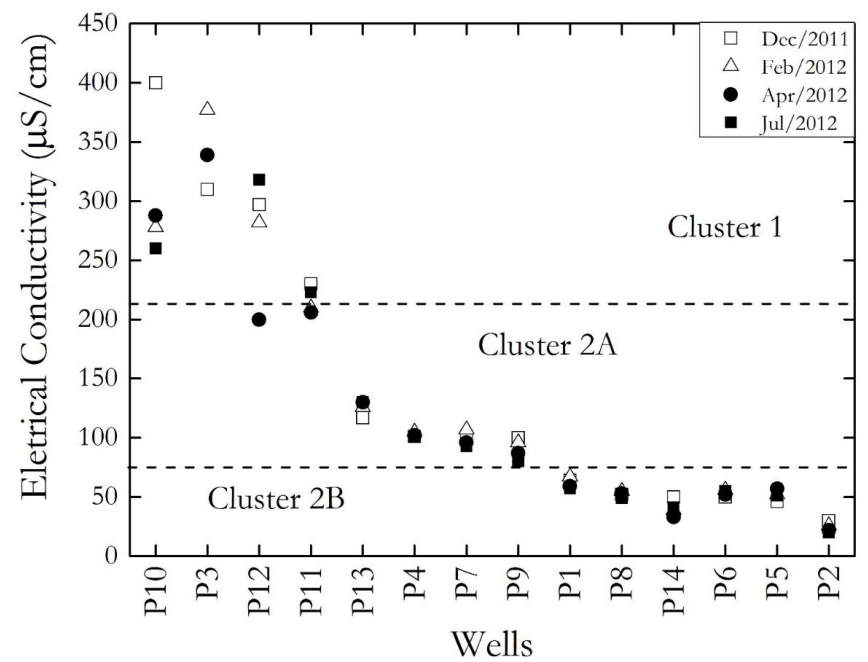

Figure 4. Electrical conductivity of the samples collected during the dry season and the rainy season.

$\left(\mathrm{SiO}_{2}\right)$. This explains the high iron concentrations with values in some places above the VMP (0.3 mg/L; BRASIL, 2008).

According to Costa (1984), in northwestern Maranhão there is occurrence of phosphatic laterites, mineral rich in iron and phosphate. The primary mineral, natural sources of phosphorus are the apatites, and are most abundant secondary calcium phosphates. In nature, phosphorus is almost exclusively as phosphate having high reactivity with clay and oxides; even in organic form as it remains phosphate (PELLEGRINI, 2005). This explains the presence of phosphorus in some samples.

Geochemistry processes associated with iron and phosphate concentrations are important for the soils used in agriculture, since when the $\mathrm{pH}$ is acid, the phosphate reacts with the iron forming compound less soluble (JENSEN, 2010), that is, on the ground phosphorous acid inorganic is fixed with iron (CH'NG; AHMED; MAJID, 2014), not being available for the plants.

The iron and phosphorus concentrations in the samples in the dry season and the rainy season, are presented in Figures 6 and 7 , respectively. 

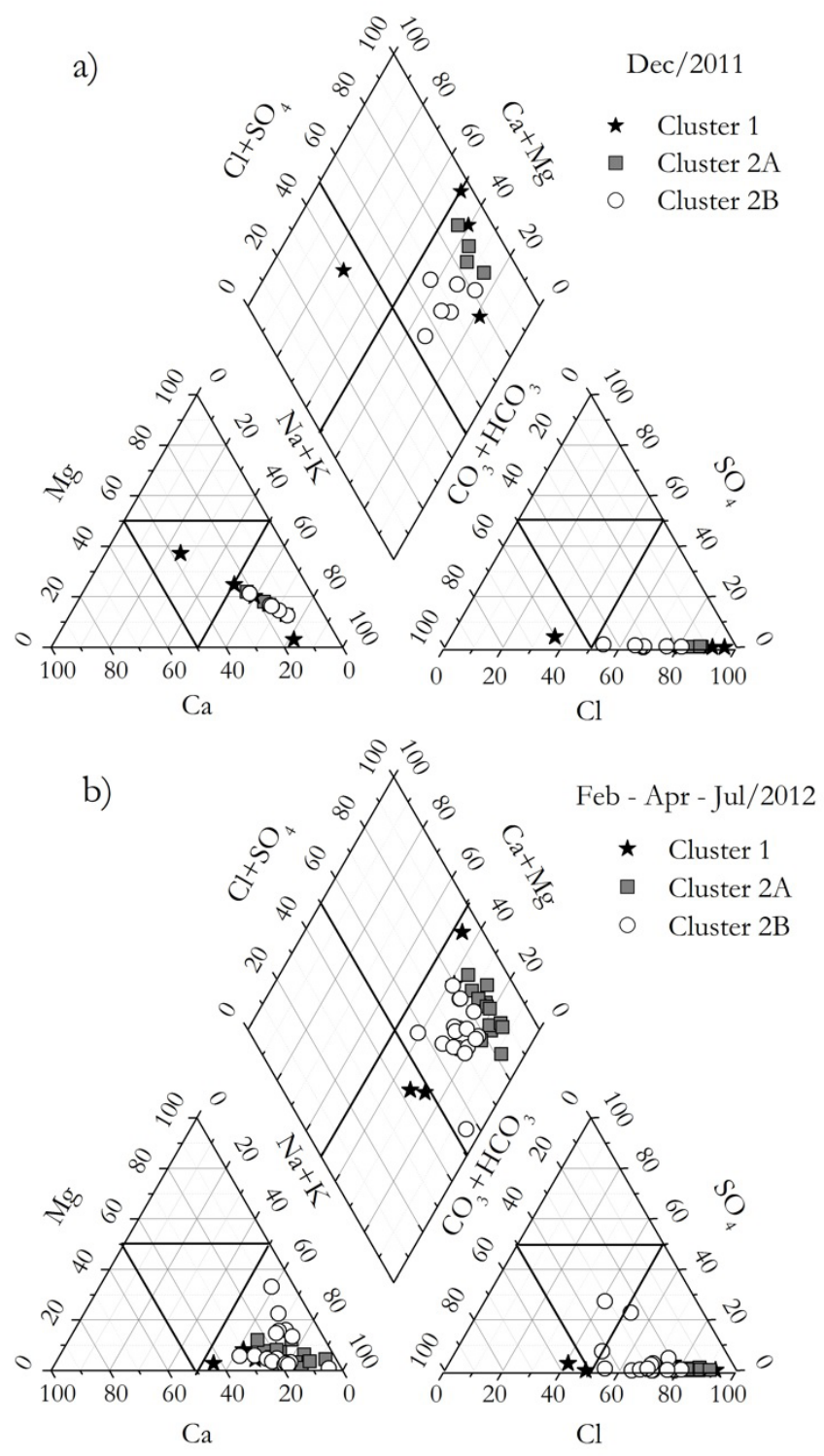

Figure 5. Piper Diagram of samples collected: (a) in the dry season and (b) in the rainy season.

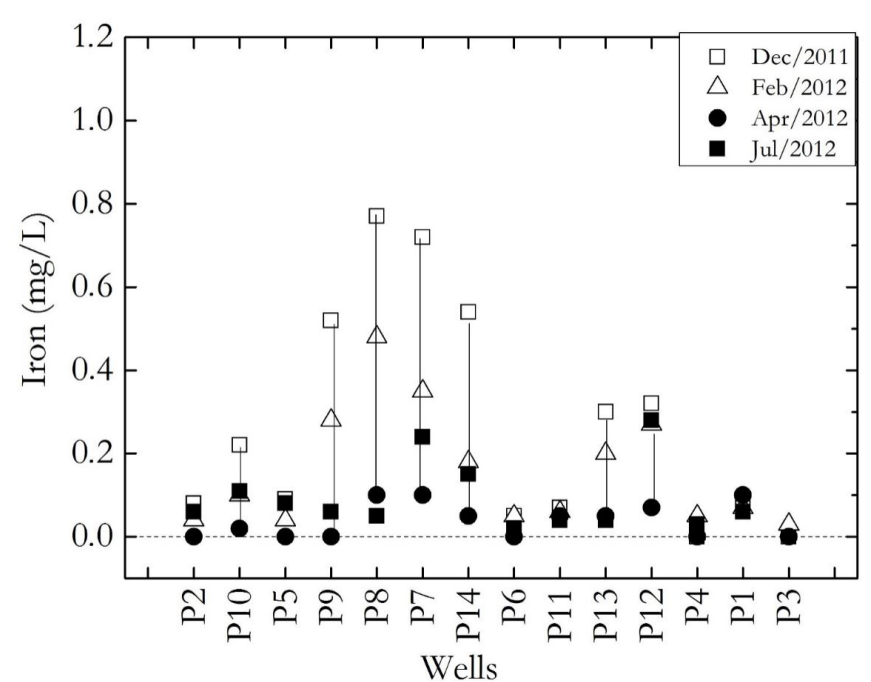

Figure 6. Wells versus concentration of iron in two collections.

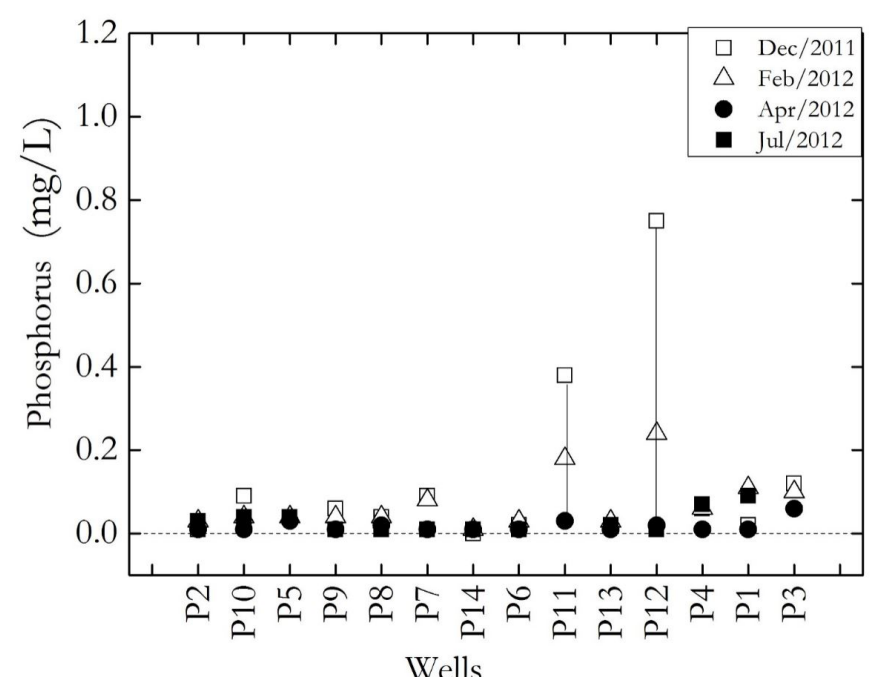

Figure 7. Wells versus phosphorus concentration in two collections. 
In Figure 6, it is observed that in eleven wells iron concentrations were higher in the dry season than in the rainy season. In Figure 7, six wells showed higher concentrations of phosphorus in the dry season than in the rainy, but only two wells (P11 and P12) with significant variations. It is important to note that the cluster analysis, despite the phosphorus concentration was not considered, these two wells (P11 and P12) were the ones who changed cluster in April (month with effective influence of recharge), suggesting a direct relationship between this parameter (phosphorus) with the aquifer system exploited.

The explanation for the local changes in iron and phosphorus concentrations is due to the dilution effect produced by the recharging. In the rainy season, the aquifer recharge containing $\mathrm{Fe}$ and $\mathrm{PO}_{4}^{3-}$, with sodium chlorinated-water type (Figure 5) producing iron chloride $\left(\mathrm{FeCl}_{3}\right)$, soluble and sodium phosphate $\left(\mathrm{Na}_{2} \mathrm{HPO}_{4}\right)$, insoluble, according to the Equation 2. This results in significant variation in iron concentration, and a small variation in the phosphorus concentration, as shown in Figures 6 and 7. The exceptions which had high phosphorus variations (P11 and $\mathrm{P} 12)$ are justified by the reaction of calcium exchange in the micelles of clayey-lenses, producing calcium phosphate $\left(\mathrm{Ca}\left(\mathrm{HPO}_{4}\right)\right)$, soluble iron carbonate $\left(\mathrm{Fe}_{2}\left(\mathrm{CO}_{3}\right)_{3}\right)$, insoluble, and hydroxide of low solubility iron. This generates greater variation in phosphorus concentration and less variation in the concentration of iron. This process described by Equation 3 occurs also when it is made liming ground to provide phosphate.

$3 \mathrm{Na}^{+}+3 \mathrm{Cl}^{-}+\mathrm{H}^{+}+\mathrm{HCO}_{3}^{-}+\mathrm{Fe}^{+3}+\mathrm{PO}_{4}^{3-} \rightarrow$

$\mathrm{FeCl}_{3}+\mathrm{Na}_{2} \mathrm{HPO}_{4}+\mathrm{NaHCO}_{3}$

$3 \mathrm{Ca}^{2+}+3\left(\mathrm{HCO}_{3}^{-}\right)+3 \mathrm{OH}^{-}+3 \mathrm{Fe}^{3+}+$

$3 \mathrm{PO}_{4}^{3-} \rightarrow 3 \mathrm{Ca}\left(\mathrm{HPO}_{4}\right)+\mathrm{Fe}_{2}\left(\mathrm{CO}_{3}\right)_{3}+\mathrm{Fe}(\mathrm{OH})_{3}$
As Itapecuru formation is divided into two members, top and bottom, where the top, which is superimposed on the formation Paleogene has as mineral limestone and clay potential (PEREIRA; ZAINE, 2007), P11 and P12 are being exploited at the interface of Paleogene formations - Itapecuru.

Although most of the wells are located in outcrop area of the hillslopes of sandy facies Barreiras Formation, without the knowledge of the water intake is not possible to identify which aquifer system each exploit. Based on the location data, depth, altitude (Table 2), cluster analysis and geochemical reactions of processes involving $\mathrm{Fe}$ and $\mathrm{PO}_{4}^{3-}$, it was possible to build a model that identifies the different exploitations of aquifers system (Figure 8).

According to the model, the wells of different cluters, exploits from different aquifers. Cluster 1, with high salinity, exploit Paleogene aquifer or aquifers at the interface of Paleogene - Itapecuru formations, with a strong contribution from the

Table 2. Location data, Altitude (A) and depth (D) of the wells.

\begin{tabular}{cccc}
\hline Wells & Coordinates - UTM $(\mathbf{m})$ & $\mathbf{A}(\mathbf{m})$ & $\mathbf{D}(\mathbf{m})$ \\
\hline P1 & $580766.42 \mathrm{E} / 9711690.84 \mathrm{~S}$ & 29 & 85 \\
P2 & $580492.00 \mathrm{E} / 9712568.88 \mathrm{~S}$ & 13 & 35 \\
P3 & $581288.08 \mathrm{E} / 9711312.86 \mathrm{~S}$ & 44 & 110 \\
P4 & $581489.03 \mathrm{E} / 9711711.92 \mathrm{~S}$ & 47 & 52 \\
P5 & $580464.00 \mathrm{E} / 9712701.00 \mathrm{~S}$ & 17 & 40 \\
P6 & $581661.74 \mathrm{E} / 9711861.66 \mathrm{~S}$ & 38 & 45 \\
P7 & $581637.29 \mathrm{E} / 9711769.93 \mathrm{~S}$ & 41 & 45 \\
P8 & $581692.90 \mathrm{E} / 9711809.11 \mathrm{~S}$ & 34 & 42 \\
P9 & $581627.95 \mathrm{E} / 9711637.93 \mathrm{~S}$ & 38 & 40 \\
P10 & $581627.84 \mathrm{E} / 9711443.93 \mathrm{~S}$ & 39 & 38 \\
P11 & $582377.42 \mathrm{E} / 9711103.42 \mathrm{~S}$ & 47 & 47 \\
P12 & $582966.22 \mathrm{E} / 9710952.31 \mathrm{~S}$ & 51 & 52 \\
P13 & $581821.71 \mathrm{E} / 9711874.47 \mathrm{~S}$ & 43 & 48 \\
P14 & $581794.19 \mathrm{E} / 9711809.39 \mathrm{~S}$ & 31 & 45 \\
\hline
\end{tabular}

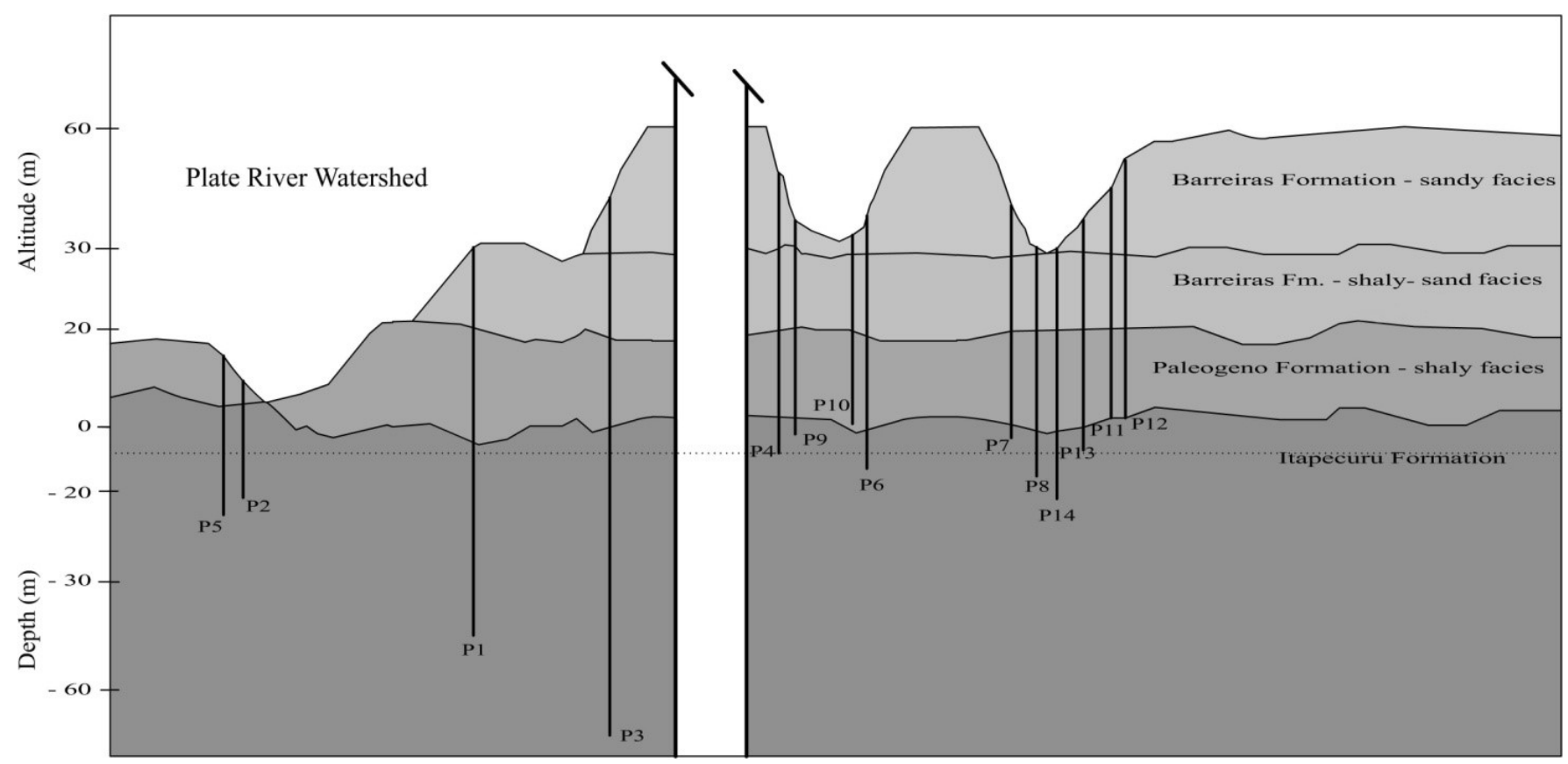

Figure 8. Model for the storage of groundwater conditions in the aquifer system in the APA Maracanã area. 
Paleogene aquifer. Except P3, which is the deepest surveyed wells and is located in different area of the other wells of your group, so in different conditions of explanation. Along with it, P1, P2 and $\mathrm{P} 5$, is in the basin of the River Plate, west Batatã reservoir, where a small dam was built (Figure 1).

Cluster 2, divided into $2 \mathrm{~A}$ and $2 \mathrm{~B}$, has all its wells exploiting from the Itapecuru formation; where the wells of the cluster 2, with intermediate salinity, exploit a depth of up to $5 \mathrm{~m}$ of this formation (dashed line in Figure 8), receiving assistance from upper limb Itapecuru aquifer; while the wells Cluster 2B with lower salinities, exploits depth greater than $5 \mathrm{~m}$, with lower limb contribution of Itapecuru aquifer.

\section{CONCLUSION}

The methodology used in this study allowed proposing a model for the storage of groundwater conditions in the aquifer system in the area. The data analysis identified separated well clusters of three groups with three different ranges of salinity, low (22 to $53 \mu \mathrm{S} / \mathrm{cm}$ ), medium (100 to $130 \mu \mathrm{S} / \mathrm{cm}$ ) and high (200 to $400 \mu \mathrm{S} / \mathrm{cm}$ ). The Piper diagrams classified as predominantly chlorinated mixed water type.

Through the analysis of geochemical processes, considering the iron and phosphorus concentrations, it was justified variations in the concentrations of these parameters. From these results, it was shown that the reserves are rapidly renewable with the arrival of the rainy season, that the less saline waters are exploited in Itapecuru aquifer with lower limb contribution of this aquifer; the ones of average salinity are from the Itapecuru aquifer, with upper limb contribution of this aquifer and the most saline waters are from the Paleogene aquifer or interface of Paleogene aquifers - Itapecuru, ensuring a contribution from the Paleogene aquifer.

This methodology applies to weather regions which favors a laterite formation where the concentration of iron and phosphorus in water is varied.

\section{REFERENCES}

BRASIL. Ministério do Meio Ambiente. Conselho Nacional do Meio Ambiente - CONAMA. Resolução CONAMA no 396, de 3 de abril de 2008. Dispõe sobre a classificação e diretrizes ambientais para o enquadramento das águas subterrâneas e dá outras providências. Diário Oficial [da] República Federativa do Brasil, Brasília, DF, 7 abr. 2008. Seção 1, p. 64-68.

BRASIL. Ministério da Saúde. Portaria no 2914, de 12 de dezembro de 2011. Dispõe sobre os procedimentos de controle e de vigilância da qualidade da água para consumo humano e seu padrão de potabilidade. Diário Oficial [da] República Federativa do Brasil, Brasília, DF, 2011.

CH'NG, H. Y.; AHMED, O. H.; MAJID, N. M. A. Improving phosphorus availability in an acid soil using organic amendments produced from agroindustrial wastes. The Scientific World Journal, v. 2014, p. 1-6, 2014. http://dx.doi.org/10.1155/2014/506356.
COSTA, M. L. A dinâmica de formação de lateritas: o exemplo do NE do Pará e do NW do Maranhão. In: CONGRESSO BRASILEIRO DE GEOLOGIA, 33., 1984, Rio de Janeiro. Anais...Rio de Janeiro: Sociedade Brasileira de Geologia, 1984. v. 4, p. $4826-4837$.

CUSTODIO, E.; LLAMAS, M. R. Hidrologia subterrânea. 2. ed. Barcelona: Omega, 1983.

GASTMANS, D.; MENEGÁRIO, A. A.; MOURA, C. C.Hidrogeoquímica das águas subterrâneas do aqüífero Serra Grande na porção centro sul do estado de São Paulo. Águas Subterrâneas, v. 27, n. 3, p. 27-44, 2013.

GÜLER, C.; THYNE, G. D.; MCCRAY, J. E.; TURNER, A. K. Evaluation of graphical and multivariate statistical methods for classification of water chemistry data. Hydrogeology Journal, v. 10, n. 4, p. 455-474, 2002. http://dx.doi.org/10.1007/s10040-002-0196-6.

HAIR JUNIOR, J. F.; BLACK, W. C.; BABIN, B. J.; ANDERSON, R. E. Análise multivariada de dados. Tradução Adonai S. Sant'Anna e Anselmo C. Neto. 5. ed. Porto Alegre: Bookman, 2005. 593 p.

IFMA - INSTITUTO FEDERAL DE EDUCAÇÃO, CIÊNCIA E TECNOLOGIA DO MARANHÃO. Projeto de Recuperação Ambiental da Mata Ciliar do Rio da Prata. São Luís: IFMA, 2009. Relatório Técnico Final Interno.

JENSEN, T. L.SoilpH and the availability of plant nutrients. Norcross: International Plant Nutrition Institute, 2010. n. 2. Available from: <http://www.ipni.net/ipniweb/pnt.nsf/0/97c1b6659f3405a2 8525777b0046bcb9/\$FILE/Plant\%20Nutrition\%20Today\%20 Fall\%202010\%202.pdf>. Access on: 10 dec. 2015.

LIMA, U. D.; MEDEIROS, C. M.; BARBOSA, D. L.; CEBALLOS, B. S. O.; RIBEIRO, M. M. R. Análise da qualidade da água subterrânea por metodologia estatística multivariada na Bacia Sedimentar do Baixo curso do Rio Paraíba. In: SIMPÓSIO BRASILEIRO DE RECURSOS HÍDRICOS, 19., 2011, Maceió. Anais... Maceió: Associação Brasileira de Recursos Hídricos, 2011. 10 p.

MENG, S. X.; MAYNARD, J. B. Use of statistical analysis to formulate conceptual models of geochemical behavoir: water chemical data from the Botucatu Aquifer in São Paulo State, Brazil.Journal of Hydrology, v. 250, n. 1-4, p. 78-87, 2001. http:// dx.doi.org/10.1016/S0022-1694(01)00423-1.

MONTEIRO, A. B.; CORREIA FILHO, F. L.; FREITE, P. K.; DE SOUZA, H. C.; SOARES FILHO, A. R. Análise estatística multivariada de dados hidroquímicos do Aquífero Cabeças sudeste da Bacia Sedimentar do Parnaíba - PI. In: CONGRESSO BRASILEIRO DE ÁGUAS SUBTERRÂNEAS, 16., ENCONTRO NACIONAL DE PERFURADORES DE POÇOS, 17., 2010, São Luís. Anais... São Luís: Associação Brasileira de Águas Subterrâneas, 2010. 19 p.

OYEBOG, S. A.; AKO, A. A.; NKENG, G. E.; SUH, E. C. Hydrochemical characteristics of some cameron bottled waters, 
investigated by multivariate statistical analyses. Journal of Geochemical Exploration, v. 112, p. 118-130, 2012. http://dx.doi.org/10.1016/j. gexplo.2011.08.003.

PELLEGRINI, J. B. R. Fósforo na água e no sedimento na Microbacia do Arroio Lino - Agudo- RS. 2005. 98 f. Dissertação (Mestrado em Ciência do Solo) - Universidade Federal de Santa Maria, Santa Maria, 2005.

PEREIRA, E. D.; ZAINE, J. E. Mapa geológico-geotécnico da Bacia do Rio Bacanga - São Luis (MA). Geociências, v. 26, n. 1, p. 45-54, 2007.

REIS, R. J. Cultura e paisagem como potencialidades econômicas na APA do Maracanã. In: REUNIÃO ANUAL DA SBPC, 64., 2012, São Luís. Anais... São Luís: Sociedade Brasileira para o Progresso da Ciência, 2012. 7 p.

SALGADO, E. V.; ANDRADE, E. M.; FONTENELE, S. B.; MEIRELES, A. C. M.Similaridade das variáveis hidroquímicas com o uso da análise multivariada na bacia do Salgado, Ceará. Revista Caatinga, v. 24, n. 3, p. 158-166, 2011.

SANTOS, S. R; SANTOS, P. C. Gestão socioambiental na área de Proteção Ambiental do Maracanã em São Luís (MA). In: ENCONTRO DA SOCIEDADE BRASILEIRA DE ECONOMIA ECOLÓGICA, 8., 2009, Cuiabá. Anais... Cuiabá: Sociedade Brasileira de Economia Ecológica. p. 1-19.

SEIDEL, E. J.; MOREIRA JUNIOR, F. J.; ANSUJ, A. P.; NOAL, M. R. C. Comparação entre o método Ward e o método K-médias no agrupamento de produtores de leite. Ciência e Natura, v. 30, n. 1, p. 7-15, 2008.

SHARMA, S. Applied multivariate techniques. New York: John Wiley \& Sons, 1996. 509 p.

SILVA, A. C.; CELINO, J. J.; ALVA, J. C. R.; SILVA, M. J. Geoestatística e Geoquímica dos metais traços na água de fontes naturais no município de Salvador-Bahia, Brasil. Águas Subterrâneas, v. 27, n. 3 , p. $16-26,2013$.

WARD JUNIOR, J. H. Hierarquical grouping to optimize an objective function. Journal of the American Statistical Association, v. 58, n. 301, p. 236-244, 1963. http://dx.doi.org/10.1080/01621 459.1963.10500845.

\section{Authors contributions}

João Batista Almeida: contributed with the field research, sampling area, periodic sampling of wells, research planning, writing and revising of the article.

João Filomeno Barros: contributed to the collection of rock testimony, locomotion of wells samples and rocks analysis in Fortaleza, helped in measurements of X-rays.

Bruno Alves de Mesquita: contributed to the analysis and data processing, charts buildings, diagrams and dendrograms, literature, formatting and revising the article.

Carla Maria Salgado Vidal Silva: contributed to the fulfillment of physico-chemical analysis of samples, revision of the article.

Josué Mendes Filho: contributed to the realization of the analysis of rocks x-rays, model planning, involving rock-pit interaction.

Horst Frischkorn: co-advisor, contributed to the research planning, literature review, revision of the article.

Maria Marlúcia Freitas Santiago: advisor, contributed to the article design, in the bibliographical research, data analysis, writing and revising the article. 